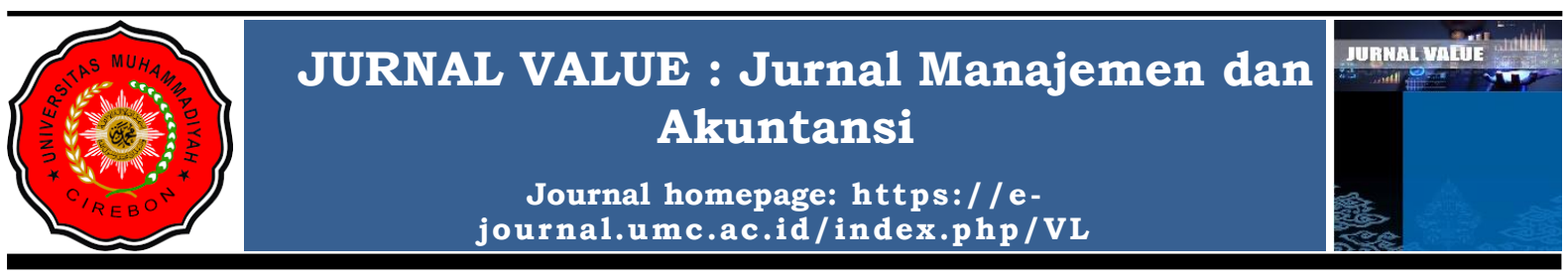

\title{
PENGARUH BRAND IMAGE DAN HARGA TIKET TERHADAP MINAT PENGUNJUNG WISATA PULAU CEMARA BREBES
}

\author{
Dumadi $^{1}$, \\ Hilda Kumala Wulandari², \\ Muhammad Syaifulloh ${ }^{3}$ \\ ${ }^{1}$ Fakultas Ekonomi dan Bisnis, Universitas Muhadi Setiabudi \\ Email : dumadi_adi@yahoo.co.id \\ ${ }^{2}$ Fakultas Ekonomi dan Bisnis, Universitas Muhadi Setiabudi \\ Email : hildakumala_wulandari@yahoo.com \\ ${ }^{3}$ Fakultas Ekonomi dan Bisnis, Universitas Muhadi Setiabudi \\ Email : msyaifulloh@umus.ac.id
}

Diterima : 3 September $2021 \quad$ Direvisi : 8 September $2021 \quad$ Dipublikasikan : 15 Oktober 2021

\begin{abstract}
Abstrak
Masalah dalam penelitian ini adalah sepinya pengunjung di masa pandemi covid 19 dan banyaknya Sektor pariwisata saat ini telah menjadi aspek penting dalam kemajuan ekonomi suatu daerah dan menjadi pilihan utama dalam pengembangan wilayah. Pembangunan suatu daerah dapat membuka daya tarik wisata baru bagi para wisatawan sehingga perlunya penerapan strategi pemasaran yang tepat akan mendatangkan wisatawan dan membuat wisatawan yang telah berkunjung memiliki minat untuk berkunjung kembali, diantaranya brand image dan harga tiket. Tujuan penelitian untuk mengetahui dan menganalisis pengaruh: 1) brand image terhadap minat pengunjung, 2) harga tiket terhadap minat pengunjung, dan 3) brand image dan harga tiket terhadap minat pengunjung pada Wisata Pulau Cemara Brebes. Populasi penelitian mengacu pada rata-rata jumlah pengunjung bulan Desember pada tahun 2020 yang berjumlah 881 pengunjung, Pengambilan sampel menggunakan rumus Slovin dengan teknik insidental sebanyak 97 orang. Data menggunakan data primer dari jawaban kuesioner. Pengujian hipotesis menggunakan SPSS 20. Landasan teori yang digunakan adalah definisi brand image, harga tiket, dan minat pengunjung. Hasil penelitian menunjukan: 1) brand image secara parsial berpengaruh signifikan terhadap minat pengunjung, 2) harga tiket secara parsial berpengaruh signifikan terhadap minat pengunjung, dan 3) brand image dan harga tiket secara simultan berpengaruh terhadap minat pengunjung.
\end{abstract}

Kata Kunci: Brand Image, Harga, Minat Pengunjung

\section{PENDAHULUAN}

Pariwisata adalah berbagai macam kegiatan wisata dan didukung berbagai fasilitas serta layanan yang disediakan oleh masyarakat, pengusaha, Pemerintah, dan Pemerintah Daerah (UU-10Tahun 2009) Pariwisata dapat memberikan kontribusi yang besar bagi pertumbuhan ekonomi negara tujuan wisata, karena memberikan kesempatan kerja, peningkatan pendapatan, perubahan taraf hidup dan kesejahteraan. Pariwisata berperan sebagai pengembangan sosial budaya dan mempromosikan citra bangsa di luar negeri. Karena Industri kepariwisataan di Indonesia merupakansalah satu penggerak perekonomian nasional yang potensial untuk memacu pertumbuhan perekonomian yang lebih tinggi di masa yang akan datang. Pembangunan sektor pariwisata dimaksudkan dapat meningkatkan pertumbuhan ekonomi, meningkatkan kesejahteraan rakyat, menghapus kemiskinan, dan mengatasi pengangguran. Pembangunan pariwisata yang bermuara kepada tujuan tersebut, pada dasarnya tidak terlepas dari peran serta masyarakat dan pemerintah daerah sebagai regulator (Mardiyani \& 
Murwatiningsih, 2015). Pariwisata saat ini sudah menjadi industri yang ikut memberikan andil dalam pembangunan ekonomi dan sosial diberbagai Negara di dunia.

Sektor pariwisata dapat memberikan kontribusi yang sangat besar bagi pertumbuhan ekonomi negara- negara tujuan wisata karena dapat memberikan kesempatan kerja, peningkatan pendapatan, perubahan taraf hidup dan kesejahteraan (Putra, Kumadji, \& Hidayat, 2015) Salah satu dari sumber daya pariwisata adalah sumber daya alam. Pengembangan sektor pariwisata yang dilakukan dengan baik akan mampu menarik wisatawan untuk datang dan membelanjakan uangnya dalam kegiatan berwisatanya (Meilisa \& Firdaus, 2018). Brebes merupakan salah satu kabupaten yang menjadi tujuan wista di Jawa Tengah yang memiliki potensi wisata alam, salah satunya adalah Pulau Cemara. Pulau ini terkenal dengan pemandangan yang indah. Pulau cemara diprakarsai oleh kelompok sadar wisata (Pokdarwis) "Pulau Cemara" pada tanggal 12 Desember 2016 dan mendapatkan Surat Keputusan Kepala Desa Sawojajar dengan nomoar 141/14/XII/2016. Kemudian pada tanggal 19 Agustus 2017 resmi menjadi berbadan hukum dengan Surat Keputusan Kemenkumham nomor AHU0015719.AH.01.07 tahun 2017. Banyak kelompok sadar wisata baru yang ada di kabupaten Brebes yang menawarkan produk jasa dalam hal ini adalah obyek wisata sebagai pemenuh kebutuhan masyarakat, maka dapat menimbulkan persaingan diantara kelompok-kelompok sadar wisata penyedia jasa. Untuk itu manajemen kelompok manapun yang mempunyai penyedia jasa akan membangun citra wisatanya agar tetap bisa dipercaya (positif) oleh konsumennya dan dapat menumbuhkan minat pengunjung. Karena Pariwisata merupakan salah satu industri di bidang jasa yang langsung berhubungan dengan konsumen akhir pengguna jasa (Indriastuty, 2020).

Citra merek yang positip akan membuat konsumen menyukai suatu produk atau jasa dengan merek bersangkutan dikemudian hari, sedangkan bagi produsen brand image yang baik dapat menghambat kegiatan pemasaran pesainnya. Karene citra merek akan menambah wisatawan untuk berkunjung, sehingga akan mendukung pemasaran yang lebih maksimal Apabila dalam suatu bisnis tidak adanya pemasaran, maka konsumen tidak akan mengetahui tentang sebuah produk yang dihasilkan dari bisnis tersebut dan membuat peminatnya menjadi rendah (Syaifulloh et al., 2021). Bila suatu merek telah memiliki citra yang positif dimata konsumen, maka konsumen akan memungkinkan untuk melakukan keputusan pembelian ulang. Produk tidak akan bisa dikenali oleh konsumennya apabila perusahaan tidak dipasarkan oleh perusahaan pembuatnya. Selain itu, dibutuhkan berbagai strategi pemasaran yang tepat agar produk yang akan dipasarkan dapat diterima dengan baik oleh pasar.

Strategi pemasaran juga dilakukan untuk membentuk persepsi atau brand image khalayak sasaran terhadap produk yang dipasarkan. Perusahaan pasti akan selalu berusaha menciptakan brand image yang positif di dalam benak khalayak sesuai dengan kebutuhan dan kondisi pelanggan. (Rossy \& Meisyaroh, 2017), Selain terdapat factor lain yang bisa mempengaruhi kunjungan wisata yaitu harga. harga merupakan salah satu variabel yang penting dalam pemasaran karena akan mempengaruhi secara langsung terhadap hasil penjualan dan pencapaian laba atau keuntungan yang ingin diperoleh perusahaan. Harga merupakan suatu cara bagi perusahaan untuk membedakan panawarannya dari para pesaing, sehingga penetapan harga dapat dipertimbangkan sebagian dari fungsi diferensiasi barang dalam pemasaran (Apriyadi, 2017).

Harga juga dapat dipahami sebagai sejumlah uang yang dibebankan atau dikenakan atas sebuah produk atau jasa. Obyek wisata Pulau Cemara menetapkan harga tiket masuk yang sangat terjangkau yaitu Rp.15.000 untuk dewasa dan Rp.5.000 untuk anak-anak, dan tiket khusus hari minggu sebesar Rp. 20.000 untuk dewasa, Rp.10.000 untuk anak-anak. Harga tiket tersebut tergolong murah dan dapat terjangkau oleh semua kalangan. Tingkat persaingan bisnis untuk meningkatkan minat pengunjung dapat diperoleh oleh beberapa hal, dalam penelitian ini difokuskan pada brand image dan harga tiket. Keinginan atau minat masyarakat yang selalu berubah-ubah dari masa ke masa memungkinkan keberadaan brand image dan harga tiket menjadi faktor dalam memilih keputusan mengunjungi obyek wisata

Tabel 1. Jumlah Pengunjung Wisata Pulau Cemara

\begin{tabular}{|c|c|c|c|c|c|}
\hline \multirow{2}{*}{ No } & \multirow{2}{*}{ Bulan } & \multicolumn{2}{|c|}{$\begin{array}{c}\text { Jumlah } \\
\text { Pengunjung }\end{array}$} & \multirow{2}{*}{ Jumlah } & \multirow{2}{*}{ Keterangan } \\
\hline & & Dewasa & $\begin{array}{l}\text { Anak- } \\
\text { Anak }\end{array}$ & & \\
\hline 1 & Januari & 4.001 & 1,575 & 5.232 & \\
\hline 2 & Februari & 1.776 & 571 & 2.347 & \\
\hline
\end{tabular}




\begin{tabular}{c|l|c|c|c|c}
3 & Maret & - & - & - & Covid-19 \\
\hline 4 & April & - & - & - & Covid-19 \\
\hline 5 & Mei & - & - & - & Covid-19 \\
\hline 6 & Juni & - & - & - & Covid-19 \\
\hline 7 & Juli & 2.011 & 75 & 2.086 & \\
\hline 8 & Agustus & 5.755 & 728 & 6.483 & \\
\hline 9 & September & 5.266 & 1.058 & 6.324 & \\
\hline 10 & Oktober & 5.797 & 1.392 & 7.189 & \\
\hline 11 & November & 1.136 & 259 & 1395 & \\
\hline 12 & Desember & 711 & 170 & 881 & \\
\hline Jumlah Pengunjung & 26.453 & 5.828 & 32.281 & \\
\hline
\end{tabular}

Sumber: Pulau Cemara Brebes, 2020

Jumlah wisatawan mengalami penurunan pada bulan Februari 2020, dimana jumlah pengunjung pada bulan Januari 2020 sebanyak 4.001 mmengalami penurunan di bulan Februari menjadi 1.776. Pada bulan April sampai dengan Juni 2020 obyek wisata ditutup karena pandemi Covid-19 dan dibuka kembali di bulan Juli 2020 dengan jumlah pengunjung 2.011. jumlah wisatawan mengalami peningkatan pada bulan Agustus sampai dengan November 2020 dengan rata-rata jumlah pengunjung selama empat bulan tersebut yaitu 6.680 pengunjung. Namun jumlah pengunjung turun kembali menjadi 881 di bulan Desember 2020. Berdasarkan data banyaknya jumlah pengunjung pada tahun 2020 dapat dikatakan berfluktuasi. Peneliti ingin mengetahui apakah dengan brand image dan harga tiket yang ada di wisata Pulau Cemara Brebes dapat menurunkan atau menaikkan minat pengunjung untuk untuk datang kembali. Berdasarkan latar belakang masalah tersebut di atas, maka saya tertarik untuk melakukan riset dengan judul "Pengaruh Brand Image dan Harga Tiket terhadap Minat Pengunjung pada Wisata Pulau Cemara Brebes.

\section{KAJIAN PUSTAKA \\ Brand Image}

Brand image atau citra merek merupakan persepsi dan keyakinan pada suatu produk. Persepsi pada merek ini dilakukan dan tersimpan oleh konsumen di dalam benaknya (Rossy \& Meisyaroh, 2017). Kepercayaan konsumen terhadap suatu merek tertentu dan bagaimana konsumen memandang suatu merek. Citra merek yang positif akan membuat konsumen menyukai suatu produk dengan merek yang bersangkutan dikemudian hari, sedangkan bagi produsen citra merek yang baik akan menghambat kegiatan pemasaran pesaing. Citra yang dibentuk sebuah perusahaan dan merupakan elemen esensial untuk mempengaruhi kesuksesan sebuah brand. Sebuah profit organization company selalu ingin mempunyai citra brand positif (Syaifulloh, 2021). Citra tersebut dapat dipersepsikan berbeda oleh setiap orang tergantung pada persepsi yang dilihat mereka mengenai perusahaan tersebut. Citra perusahaan yang di dapat oleh perusahaan karena adanya keunggulan-keunggulan yang ada pada perusahaan tersebut, sehingga perusahaan akan bisa mengembangkan dirinya menciptakan hal-hal yang baru lagi bagi pemenuhan kebutuhan dan keinginan konsumen (Putra et al., 2015)

Menurut (Rossy \& Meisyaroh, 2017) brand image memiliki tiga komponen yaitu corporate image (citra perusahaan), user image (citra Pemakai), dan product image (citra produk).

1. Citra Pembuat (Corporate Image) adalah sekumpulan asosiasi yang dipersepsikan konsumen terhadap perusahaan yang membuat suatu produk dan jasa.

2. Citra Pemakai (User Image) adalah sekumpulan asosiasi yang dipersepsikan konsumen terhadap pemakai yang menggunakan barang atau jasa, meliputi pemakai itu sendiri, gaya hidup atau kepribadian status sosial.

3. Citra Produk (Product Image) adalah sekumpulan asosiasi yang dipersepsikan konsumen terhadap suatu produk, yang meliputi atribut produk tersebut, manfaat bagi konsumen, penggunaannya, serta jaminan.

Menurut Low and Lamb dalam (Armawati, Saryadi, \& Prabawani, 2014) mengemukakan indikator dari brand image antara lain :

1. friendly / unfriendly: kemudahan dikenali oleh konsumen.

2. Modern / outdated : memiliki model yang up to date / tidak ketinggalan jaman. 
3. useful / not : dapat digunakan dengan baik/ bermanfaat

4. popular / unpopular : akrab di benak konsumen

5. gentle / harsh : mempunyai tekstur produk halus / tidak kasar

6. artificial / natural : keaslian komponen pendukung atau bentuk Perceived

\section{Harga Tiket}

Harga merupakan suatu cara bagi perusahaan untuk membedakan panawarannya dari para pesaing, sehingga penetapan harga dapat dipertimbangkan sebagian dari fungsi diferensiasi barang dalam pemasaran. menyatakan bahwa harga adalah sejumlah uang sebagai alat tukar untuk memperoleh produk atau jasa. Menurut (Apriyadi, 2017) Harga adalah jumlah uang (ditambah beberapa produk kalau mungkin) yang dibutuhkan untuk mendapatkan sejumlah kombinasi dari produk dan pelayanannya. Atau dapat juga di artikan suatu nilai yang dinyatakan dalam bentuk rupiah guna pertukaran atau taransaksi atau sejumlah uang yang harus dibayar konsumen untuk mendapatkan barang dan jasa (Given, 2012). Jadi dapat dipahami bahwa harga tiket merupakan jumlah dari nilai yang dipertukarkan pengunjung dengan sebuah tiket untuk mendapatkan manfaat atau menggunakan suatu produk atau jasa dalam hal ini berwisata. Ada empat ukuran atau indikator yang mencirikan mengenai harga yaitu sebagai berikut Keterjangkauan Harga. Konsumen bisa menjangkau harga yang telah ditetapkan oleh perusahaan.

1. Kesesuaian harga dengan kualitas produk. Apabila harga lebih tinggi orang cenderung beranggapan bahwa kualitasnya juga lebih baik.

2. Kesesuaian harga dengan manfaat. Konsumen memutuskan membeli suatu produk jika manfaat yang dirasakan lebih besar atau sama dengan yang dikeluarkan untuk mendapatkannya.

\section{Minat Pengunjung}

Teori minat berkunjung dalam hal ini diambil dari teori minat beli terhadap suatu produk, sehingga dalam beberapa kategori minat berkunjung dapat diaplikasikan terhadap minat beli. Pada dasarnya minat berkunjung adalah perasaan ingin mengunjungi suatu tempat atau wilayah yang menarik untuk dikunjungi, sehingga dalam beberapa kategori minat berkunjung dapat diaplikasikan dari model minat beli. minat membeli merupakan aktivitas psikis yang timbul karena adanya perasaan dan pikiran terhadap suatu barang atau jasa yang diinginkan (Putra et al., 2015). Fenomena yang banyak terjadi saat ini adalah wisatawan melakukan kunjungan ke suatu destinasi tidak hanya karena ingin menikmati atraksi ataupun mencari hiburan, melainkan untuk mengabadikan momen melalui foto atau video. Foto atau video tersebut selanjutnya akan dibagikan di media atau aplikasi yang memungkinkan manusia untuk saling berinteraksi secara virtual yang biasa disebut dengan media sosial (Isnaini \& Abdillah, 2018).

Dimensi minat beli adalah melalui model stimulasi AIDA yang berusaha menggambarkan tahap-tahap rangsangan yang mungkin dilalui oleh konsumen terhadap suatu rangsangan tertentu yang diberikan oleh pemasar, yaitu sebagai berikut:

1. Perhatian (Attention), dalam tahap ini masyarakat pernah mendengar mengenai perusahaan atau produk yang dikeluarkan perusahaan.

2. Minat (Interest), minat masyarakat timbul setelah mendapatkan dasar informasi yang lebih terperinci mengenai perusahaan atau produk.

3. Kehendak (Desire), masyarakat mempelajari, memikirkan serta berdiskusi yang menyebabkan keinginan dan hasrat untuk membeli produk tersebut bertambah.

4. Tindakan (Action), melakukan pengambilan keputusan yang positif atas penawaran perusahaan.

\section{METODE PENELITIAN}

Jenis penelitian ini yaitu termasuk penelitian dengan pendekatan kuantitatif. Populasi penelitian ini diambil dengan mengambil sejumlah 881 wisatawan pada bulan desember 2020. Adapun penelitian ini menggunakan rumus Slovin dalam penarikan sampel, diperoleh sampel sejumlah 97 wisatawan sebagai berikut :

Tabel 2. Populasi dan sampel

\begin{tabular}{clccc}
\hline No & & Jenis kelamin & Populasi & Sampel \\
\hline 1 & Dewasa & 711 & 66 \\
\hline 2 & Anak anak & 170 & 33 \\
\hline & Jumlah & 881 & 97 \\
\hline
\end{tabular}


Metode pengumpulan data dengan cara membagikan Angket/Kuesioner dengan skala likert yang terlebih dahulu di uji cobakan ke pengunjung Wisata Pantai Randusanga Indah, setalah Angket valid kemudian di berikan ke sampel di Pantau Pulau, Sedangkan untuk analisis data dengan cara Uji Validitas dan Reabilitas, Uji Asumsi Klasik, Uji Hipotesis, Uji t dan Uji F.

\section{HASIL PENELITIAN DAN PEMBAHASAN Uji Validitas dan Reabilitas}

Data penelitian ini berasal dari jawaban sebarang kuesioner terkait dengan brand image, harga tiket, dan minat pengunjung. Sebelum data di analisis terlebih dahulu diuji validitas dan reliabilitasnya. Uji validitas dilakukan menggunakan rumus corelation produk moment dari Pearson. Hasil perhitungan diperoleh indek validitas dari semua item kuesioner baik dari variabel $\mathrm{X}_{1}, \mathrm{X}_{2}$, dan Y lebih besar dari $\mathrm{r}$ tabel pada tingkat signifikan 0,05 dengan $\mathrm{n}=97$, diketahui $\mathrm{R}$ table $=0,195$ atau nilai Sig kurang dari 0,05 .

Tabel 3. Validitas Angket

\begin{tabular}{|c|c|c|c|c|}
\hline \multicolumn{5}{|c|}{ Correlations } \\
\hline & & Brand Image & Harga Tiket & Minat Pengunjung \\
\hline \multirow[t]{3}{*}{ Item 1} & Pearson Correlation &, $572^{* * *}$ & $648^{* *}$ &, $528^{* *}$ \\
\hline & Sig. (2-tailed) &, 000 &, 000 &, 000 \\
\hline & $\mathrm{N}$ & 97 & 97 & 97 \\
\hline \multirow[t]{3}{*}{ Item 2} & Pearson Correlation &, $577^{* *}$ & $662^{* *}$ & $800^{* *}$ \\
\hline & Sig. (2-tailed) &, 000 &, 000 &, 000 \\
\hline & $\mathrm{N}$ & 97 & 97 & 97 \\
\hline \multirow{3}{*}{ Item 3} & Pearson Correlation &, $643^{* *}$ &, $595^{* *}$ & $674^{* *}$ \\
\hline & Sig. (2-tailed) &, 000 & ,000 & ,000 \\
\hline & $\mathrm{N}$ & 97 & 97 & 97 \\
\hline \multirow[t]{3}{*}{ Item 4} & Pearson Correlation & $433^{* *}$ &, $656^{* *}$ &, $800^{* * *}$ \\
\hline & Sig. (2-tailed) &, 000 & , 000 & ,000 \\
\hline & $\mathrm{N}$ & 97 & 97 & 97 \\
\hline \multirow[t]{3}{*}{ Item 5} & Pearson Correlation & $695^{* *}$ &, $502^{* *}$ & $674^{* *}$ \\
\hline & Sig. (2-tailed) & , 000 &, 000 & ,000 \\
\hline & $\mathrm{N}$ & 97 & 97 & 97 \\
\hline \multirow{3}{*}{ Item 6} & Pearson Correlation & $611^{* * *}$ & $654^{* * *}$ & $620^{* * *}$ \\
\hline & Sig. (2-tailed) & 000 & ,000 & 000 \\
\hline & $\mathrm{N}$ & 97 & 97 & 97 \\
\hline \multirow[t]{3}{*}{ Item 7} & Pearson Correlation &, $572^{* * *}$ & $649^{* *}$ &, $705^{* *}$ \\
\hline & Sig. (2-tailed) & ,000 &, 000 & 000 \\
\hline & $\mathrm{N}$ & 97 & 97 & 97 \\
\hline \multirow[t]{3}{*}{ Item 8} & Pearson Correlation & $472^{* *}$ &, $575^{* *}$ & $438^{* *}$ \\
\hline & Sig. (2-tailed) &, 000 & , 000 &, 000 \\
\hline & $\mathrm{N}$ & 97 & 97 & 97 \\
\hline
\end{tabular}

*. Correlation is significant at the 0.05 level (2-tailed).

**. Correlation is significant at the 0.01 level (2-tailed).

Sumber : Hasil olah data SPSS 20.0 (2021)

Uji reliabilitas dilakukan dengan menggunakan rumus Alpha. Suatu instrumen dapat dipercaya atau reliabel apabila nilai Cronbach Alpa diatas 0,70.

Tabel 4. Hasil Uji Reliabilitas Instrumen $X_{1}, X_{2}$, dan $Y$

\begin{tabular}{|c|c|c|c|c|c|}
\hline \multicolumn{6}{|c|}{ Reliability Statistics } \\
\hline \multicolumn{2}{|c|}{$\mathrm{X} 1$} & \multicolumn{2}{|c|}{$\mathrm{X} 2$} & \multicolumn{2}{|c|}{$\mathrm{Y}$} \\
\hline $\begin{array}{c}\text { Cronbach's } \\
\text { Alpha }\end{array}$ & $\mathrm{N}$ of Items & $\begin{array}{c}\text { Cronbach's } \\
\text { Alpha }\end{array}$ & $\mathrm{N}$ of Items & $\begin{array}{c}\text { Cronbach's } \\
\text { Alpha }\end{array}$ & $\mathrm{N}$ of Items \\
\hline ,703 & 8 & ,770 & 8 & ,809 & 8 \\
\hline
\end{tabular}

Sumber : Hasil olah data SPSS 20.0 (2021)

Berdasarkan out put SPSS 20.0 pada tabel 3 di atas, dapat diketahui bahwa nilai Cronbach's alpha dari variabel $\mathrm{X}_{1}$ (brand image) sebesar 0,703, $\mathrm{X}_{2}$ (harga tiket) sebesar 0,770, dan $\mathrm{Y}$ (minat pengunjung) sebesar 0,809. Nilai Cronbach's Alfa ketiga variabel tersebut $\geq 0,70$ yang artinya mempunyai nilai reliabilitas tinggi. Jadi data yang dihasilkan dari kuesioner tentang brand image, harga 
tiket dan minat pengunjung tersebut dikatakan reliabel. Jadi berdasarkan hasil uji validitas dan reliabilitas instrumen, dapat diketahui ketiga instrumen tersebut baik tentang brand image, harga tiket, dan minat pengunjung telah memenuhi kriteria validitas dan reliabilitas. Dengan demikian data tersebut layak digunakan untuk penelitian.

\section{Uji Asumsi Klasik}

Untuk keperluan analisis data dilakukan uji asumsi klasik: uji normalitas, uji multikolineritas dan uji heteroskedastisitas. Penelitian uji normalitas menggunakan grafik histogram dan kurva penyebaran P-Plot, yang digambarkan sebagai berikut:

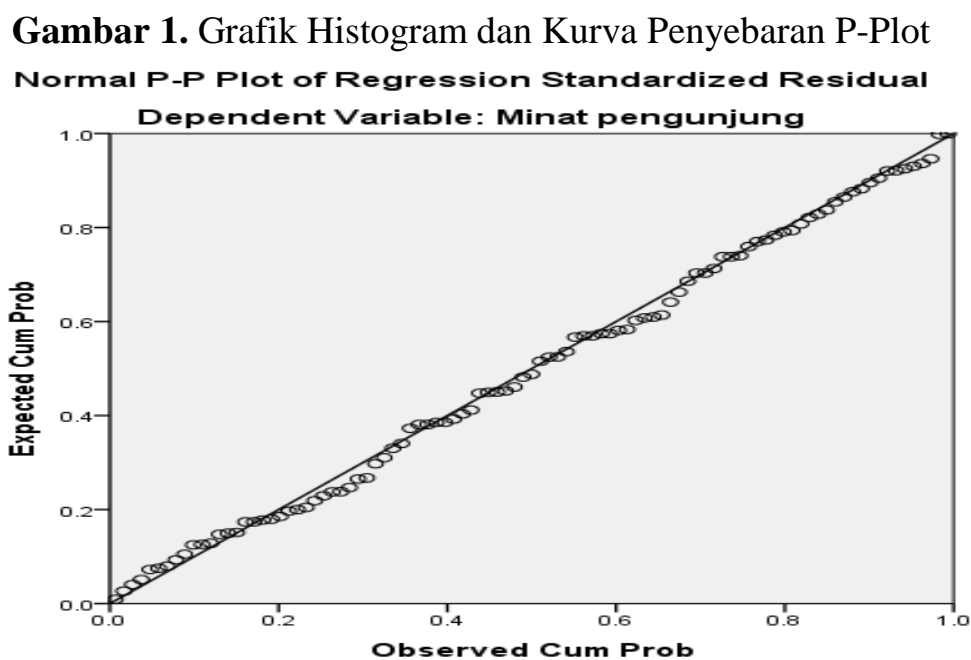

Sumber : Hasil olah data SPSS 20.0 (2021)

Berdasarkan grafik normal P-P Plot di atas, dapat dilihat bahwa titik menyebar disekitar garis diagonal dan penyebarannya mengikuti garis diagonal, sehingga dapat dikatakan bahwa pola distribusinya normal. Grafik di atas menunjukkan bahwa model regresi pengaruh brand image dan harga tiket terhadap minat pengunjunag penelitian ini memenuhi asumsi normalitas. Hasil ini uji Kolmogorov-Smirnov, nilai signigikansi lebih besar 0,05 maka data tersebut berdistribusi normal. Berdasarkan out put SPSS 20.0 pada tabel 4 diperoleh nilai Probability Sig (2 tailed) dengan Asymp.sig sebesar 0,990 lebih besar dari 0,05, maka disimpulkan data tersebut telah terdistribusi secara normal atau berdistribusi normal.

Tabel 5. Uji Normalitas Kolmogorov-Smirnov One-Sample Kolmogorov-Smirnov Test

\begin{tabular}{llr} 
& & Unstandardized Residual \\
\hline N & & 97 \\
\hline Normal Parameters & Mean &, $0 \mathrm{E}-7$ \\
\cline { 2 - 3 } & Std. Deviation & 3,10553321 \\
\hline Most Extreme Differences & Absolute &, 045 \\
\cline { 2 - 3 } & Positive &, 045 \\
\cline { 2 - 3 } & Negative &,- 030 \\
\hline Test Statistic & &, 441 \\
\hline Asymp. Sig. (2-tailed) & &, $990^{\text {c,d }}$ \\
\hline
\end{tabular}
a. Test distribution is Normal.
b. Calculated from data.
c. Lilliefors Significance Correction.
$\mathrm{d}$. This is a lower bound of the true significance.
Sumber : Hasil olah data SPSS 20.0 (2021)

Uji multikolonieritas diperoleh hasil bahwa variabel brand image dan harga tiket bebas dari multikolonieritas yang ditunjukan dengan nilai tolerance $>0,10$ atau nilai VIF $<10$. Berdasarkan out put SPSS 20.0 pada tabel 5 hasil uji multikolonieritas pada bagian Collinearity Statistics terlihat untuk kedua variabel independen mempunyai angka Tolerance sebesar 0,965 lebih besar dari 0,10. Sedangkan nilai VIF sebesar 1,036 lebih kecil dari 10. Dengan demikian hasil tersebut tidak melebihi batas nilai 
Tolerance dan VIF yang diperkenankan, maka dapat disimpulkan bahwa model regresi yang dihasilkan tidak ada masalah multikolonieritas.

Tabel 6. Uji Multikolonieritas

\begin{tabular}{ll|l|l}
\hline \multicolumn{4}{c}{ Coefficients $^{\mathbf{a}}$} \\
\hline \multirow{3}{*}{ Model } & \multicolumn{3}{|c}{ Collinearity Statistics } \\
& & Tolerance & VIF \\
\hline 1 & (Constant) &, 965 & 1,036 \\
\cline { 2 - 4 } & Brand image &, 965 & 1,036 \\
\cline { 2 - 4 } & Harga tiket & & \\
\hline \multicolumn{2}{l}{ a. Dependent Variable: Minat Pengunjung } \\
\hline
\end{tabular}

Sumber : Hasil olah data SPSS 20.0 (2021)

Uji heteroskedastisitas bertujuan menguji apakah dalam model regresi terjadi ketidaksamaan variance dari residual satu pengamatan ke pengamatan yang lain. Jika variance tetap maka terjadi homoskedastisitas dan jika berbeda maka terjadi problem heteroskedastisitas. Model regresi yang baik yaitu homoskesdatisitas atau tidak terjadi heterokedasitas. Salah satu cara mengetahui ada tidaknya heteroskedastisitas dalam suatu model regresi linier berganda yaitu dengan melihat grafik scatterplot antara nilai prediksi variabel terikat yaitu SRESID dengan residual error yaitu ZPRED. Jika tidak ada pola tertentu dan titik menyebar di atas dan dibawah angka 0 pada sumbu Y, maka tidak terjadi heteroskedastisitas. Grafik scatterplot pada penelitian ini ditunjukan pada grafik berikut:

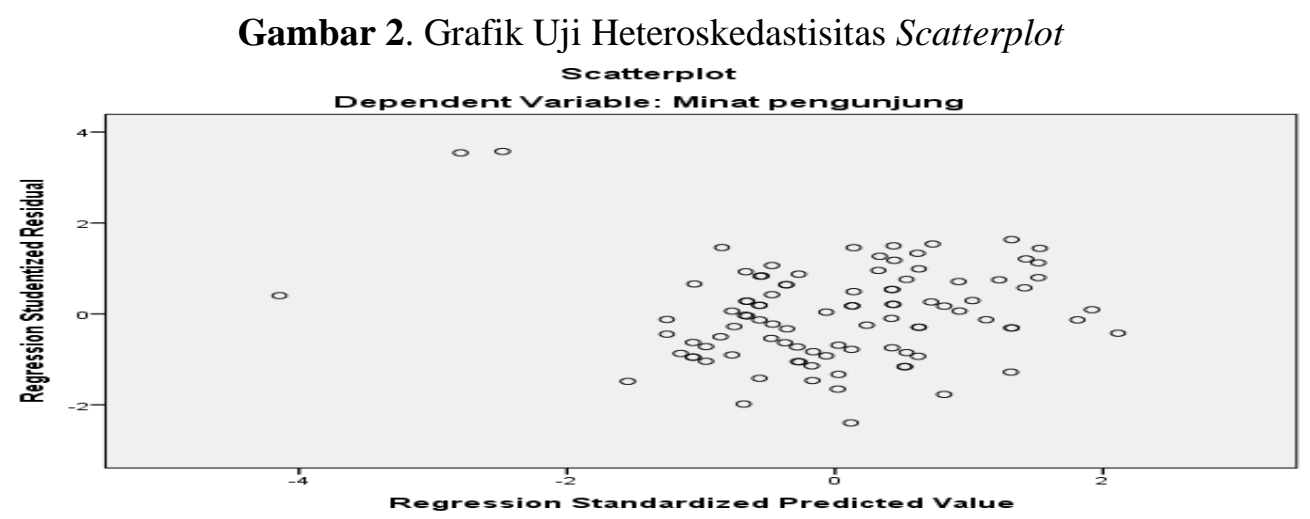

Sumber : Hasil olah data SPSS 20.0 (2021)

Dilihat dari hasil uji heteroskedastisitas dengan grafik scatterplot terlihat bahwa titik-titik menyebar secara acak serta tersebar baik diatas maupun di bawah angka 0 pada sumbu Y. Dengan demikian dinyatakan bahwa model regresi ini tidak terjadi gejala heteroskedastisitas. Berdasarkan uji asumsi klasik, dapat diketahui bahwa data yang diperoleh dari sebarang kuesioner telah memenuhi uji normalitas, uji multikolineritas dan uji heteroskedastisitas. Uji hipotesis dalam penelitian ini meliputi uji parsial dan uji simultan. Pengujian secara parsial (uji t) dilakukan untuk menentukan apakah brand image dan harga tiket berpengaruh terhadap minat pengunjung secara parsial (individu). Adapun penerimaan atau penolakan hipotesis dilakukan dengan kriteria, jika nilai signifikansi t statistik $>0,05$, maka Ho diterima, artinya suatu variabel independen secara individual tidak berpengaruh terhadap variabel dependen. Sebaliknya jika nilai signifikansi t statistik $<0,05$, maka Ho ditolak, artinya suatu variabel independen secara individual berpengaruh terhadap variabel dependen.

Tabel 7. Hasil Pengujian Parsial (Uji t)

\begin{tabular}{|c|c|c|c|c|c|c|}
\hline \multicolumn{7}{|c|}{ Coefficients $^{a}$} \\
\hline \multirow{2}{*}{\multicolumn{2}{|c|}{ Model }} & \multicolumn{2}{|c|}{ Unstandardized Coefficients } & \multirow{2}{*}{$\begin{array}{c}\text { Standardized Coefficients } \\
\text { Beta }\end{array}$} & \multirow[b]{2}{*}{$\mathrm{t}$} & \multirow[b]{2}{*}{ Sig. } \\
\hline & & $\mathrm{B}$ & Std. Error & & & \\
\hline 1 & (Constant) & 4,480 & 2,945 & & 1,521 & ,132 \\
\hline & Brand Image & , 287 &, 082 & ,267 & 3,505 & ,001 \\
\hline & Harga Tiket & ,589 & 077 & ,586 & 7,692 &, 000 \\
\hline
\end{tabular}

a. Dependent Variable: Minat Pengunjung

Sumber : Hasil olah data SPSS 20.0 (2021) 
Dari out put SPSS 20.0 pada tabel 7 di atas menunjukkan hasil uji t adalah:

1. Nilai signifikan $\mathrm{t} X_{1}=0,001$. Hasil nilai signifikan t $X_{1}$ lebih kecil dari 0,05 atau $0,001<0,05$, maka disimpulkan Ho ditolak dan Ha diterima artinya brand image secara parsial atau individu berpengaruh positif dan signifikan terhadap minat pengunjung. Kesimpulannya bahwa hipotesis pertama diterima.

2. Nilai signifikan $\mathrm{t} \mathrm{X}_{2}=0,000$. Hasil nilai signifikan $\mathrm{t} \mathrm{X}_{2}$ lebih kecil dari 0,05 atau $0,000<0,05$, maka disimpulkan Ho ditolak dan Ha diterima artinya harga tiket secara parsial atau individu berpengaruh positif dan signifikan terhadap minat pengunjung. Kesimpulannya bahwa hipotesis kedua diterima.

Untuk uji hipotesis ketiga, digunakan analisis Uji F. Uji F pada dasarnya menunjukkan apakah semua variabel independen yang dimasukan dalam model regresi mempunyai dampak secara bersamasama terhadap variabel dependennya. Berikut hasil analisis uji statistik $\mathrm{F}$ dengan bantuan program SPSS.

Tabel 8. Hasil Pengujian Simultan (Uji F)

ANOVA $^{\mathrm{a}}$

\begin{tabular}{|c|c|c|c|c|c|c|}
\hline \multicolumn{2}{|c|}{ Model } & Sum of Squares & $\mathrm{df}$ & Mean Square & $\mathrm{F}$ & Sig. \\
\hline \multirow[t]{2}{*}{1} & Regression & 832,639 & 2 & 416,319 & 42,268 &, $000^{\mathrm{b}}$ \\
\hline & Residual & 925,856 & 94 & 9,850 & & \\
\hline
\end{tabular}

a. Dependent Variable: Minat Pengunjung

b. Predictors: (Constant), brand image, harga tiket

Sumber : Hasil olah data SPSS 20.0 (2021)

Berdasarkan out put SPSS 20.0 pada tabel 8 di atas, menunjukkan nilai signifikansi F sebesar 0.000. Adapun kriteria pengujian menentukan bahwa jika nilai probabilitas (Sig) $<0,05$, Dengan demikian karena $0,000<0,05$, hipotesis penelitian diterima. maka dapat disimpulkan bahwa variabel independen brand image dan harga tiket secara simultan bersama-sama berpengaruh signifikan terhadap variabel dependen minat pengunjung. Kesimpulannya hipotesis ketiga diterima. Selanjutnya hasil koefisien determinasi $\left(\mathrm{R}^{2}\right)$ bertujuan untuk mengukur seberapa jauh kemampuan model regresi dalam menjelaskan variasi variabel dependen. Nilai $R^{2}$ menunjukkan kemampuan brand image dan harga tiket berpengaruh terhadap minat pengunjung. Berikut hasil koefisien determinasi.

Tabel 9. Koefisien Determinasi

$$
\text { Model Summary }{ }^{b}
$$

\begin{tabular}{lc|c|c|c} 
Model & $\mathrm{R}$ & $\mathrm{R}$ Square & Adjusted R Square & Std. Error of the Estimate \\
\hline 1 &, $688^{\mathrm{a}}$ &, 473 &, 462 & 3,138 \\
\hline
\end{tabular}

a. Predictors: (Constant), Brand image, Harga tiket

b. Dependent Variable: Minat Pemgunjung

Sumber : Hasil olah data SPSS 20.0 (2021)

\section{Uji Hipotesis}

Setelah data memenuhi uji asumsi klasik, kemudian dilakukan pengujian tahap akhir yaitu uji hipotesis. Dalam penelitian ini analisis regresi linier berganda digunakan untuk menguji pengaruh antara variabel bebas terhadap variabel terikat. Bentuk umum persamaan regresi linier berganda sebagai berikut:

Tabel 10. Hasil Uji Analisis Regresi Linier Berganda

\begin{tabular}{llc|c|c}
\hline \multicolumn{5}{c}{ Coefficients $^{\mathbf{a}}$} \\
\hline \multirow{2}{*}{ Model } & & \multicolumn{4}{c}{$\begin{array}{c}\text { Unstandardized Coefficients } \\
\text { B }\end{array}$} & $\begin{array}{c}\text { Standardized Coefficients } \\
\text { Beta }\end{array}$ \\
\hline \multirow{2}{*}{1} & & B & Std Error & \\
\cline { 2 - 5 } & Brand Image &, 480 & 2,945 &, 267 \\
\cline { 2 - 5 } & Harga Tiket &, 589 &, 082 &, 586 \\
\hline
\end{tabular}

a. Dependent Variable: Minat Pengunjung

Sumber : Hasil olah data SPSS 20.0 (2021)

Berdasarkan output SPSS 20.0 diperoleh nilai constant sebesar -4,480, koefisien $\mathrm{X}_{1}=0,267$ dan koefisien $\mathrm{X}_{2}=0,586$. Jadi persamaan regresi linear berganda pengaruh kualitas layanan dan sarpras terhadap minat pengunjung adalah $\mathrm{Y}=4,480-0,267 \mathrm{X}_{1}+0,586 \mathrm{X}_{2}$. 


\section{PEMBAHASAN}

Berdasarkan persamaan dari model regresi linier berganda tersebut dapat disimpulkan bahwa:

1. Variabel brand image (X1) memiliki nilai koefisien regresi sebesar 0,267. Nilai koefisien ini menunjukkan hubungan positif brand image terhadap minat pengunjung. Hal ini berarti jika terjadi brand image dinaikan sebesar 1\%, maka akan meningkatkan minat pengunjung sebesar 0,267 dengan asumsi variabel independen yang lain yaitu harga tiket dianggap konstan atau tetap. Berdasarkan hasil tersebut maka dapat di simpulkan bahwa band image berpengaruh terhadap Minat, Selaras dengan penelitian dari (Negara \& Nuralam, 2018) dan (Cece, 2015) yakni Hasil penelitiannya menunjukkan Pengaruh Brand Image terhadap Minat.

2. Variabel Harga tiket (X2) memiliki nilai koefisien regresi sebesar 0,586. Nilai koefisien ini menunjukkan hubungan positif harga tiket terhadap minat pengunjung. Hal ini berarti jika terjadi peningkatan harga tiket sebesar $1 \%$, maka akan meningkatkan minat pengunjung sebesar 0,586 dengan asumsi variabel independen yang lain yaitu brand image dianggap konstan atau tetap. Berdasarkan hasil tersebut dapat disimpulkan Harga Tiket merupakan faktor yang mempengaruhi minat Pengunjung. Hasil tersebut juga membuktikan kebenaran dari penelitian sebelumnya oleh (Rizky \& Yasin, 2014) dan (Aptaguna \& Pitaloka, 2016) bahwa Harga berpengaruh terhadap Minat.

3. Variabel brand image (X1) dan Variabel harga tiket (X2) secara bersama sama memiliki pengaruh dengan Nilai konstanta sebesar 4,480. Artinya angka tersebut menunjukkan bahwa jika brand image (X1) dan harga tiket (X2), maka nilai minat pengunjung (Y) akan naik sebesar 4,480.

\section{KESIMPULAN}

Berdasarkan hasil penelitian yang telah diuraikan pada bab sebelumnya, dapat disimpulkan brand image, harga tiket berpengaruh positif dan signifikan terhadap minat pengunjung pada wisata Pulau Cemara Brebes. Minat pengunjung merupakan dorongan yang mengakibatkan perhatian atau ketertarikan seseorang kepada suatu objek wisata. Minat mengunjungi suatu wisata merupakan kegiatan yang dipilih sendiri dan menyenangkan sehingga dapat membentuk suatu kebiasaan dalam diri seseorang untuk berkunjung ulang. Tujuan perjalanan wisata dilakukan semata-mata untuk bersenangsenang tanpa mencari nafkah di Negara Kota atau daerah tempat wisata yang dikunjungi sehingga brand image dan harga tiket perlu diperhitungkan oleh pengelola obyek wisata. Pengelolaan yang kurang maksimal dari Pulau Cemara menyebabkan brand image kurang diperhatikan sehingga tidak konsisten, terkadang brand image baik namun ada kalanya brand image kurang baik sehingga mempengaruhi minat pengunjung. Begitu juga dengan harga tiket di Pulau Cemara perlu adanya evaluasi atau ditinjau, karena harga tiket dapat menurunkan minat pengunjung.

\section{SARAN}

Adapun Saran dari penelitian ini adalah Brand Image yang sudah baik harus selalu dijaga, karena sangat penting untuk meningkatkan minat pengunjung, harga Tiket selayakna juga menyesuaikan penghasilan dari UMR daerah setempat sehingga tetap terjaga Jumlah pengunjung bahkan bisa meningkat setiap harinya, sehingga Tujuan dari Visi pulau cemara bisa tercapai, Untuk para peneliti selanjutnya mencari Faktor faktor lain yang lebih besar pengaruhnya terhadap minat pengunjung, seperti Promosi dan dukungan pemerintah.

\section{REFERENSI}

Apriyadi, Dede. (2017). Analisis Pengaruh Ketepatan Waktu , Fasilitas Kereta Api Di Stasiun Purwosari. Magistra, 29(99), 71-83.

Aptaguna, Angga, \& Pitaloka, Endang. (2016). Pengaruh Kualitas Layanan Dan Harga Terhadap Minat Beli Jasa Go-Jek. Widyakala Journal, 3(2012), 49. https://doi.org/10.36262/widyakala.v3i0.24

Armawati, Isna, Saryadi, \& Prabawani, Bulan. (2014). Pengaruh Brand Awareness , Brand Image Dan Perceived Quality Terhadap Keputusan Pemakaian Jasa Pada Maskapai Penerbangan Garuda Indonesia. Jurnal Ilmu Administrasi Bisnis, 3(4), 1-9.

Cece, Ike Sen. (2015). Pengaruh Brand Origin, Brand Ambassador dan Brand Image Terhadap Minat Beli Sepatu Macbeth di Sogo Galaxy Mall Surabaya. Manajemen Kinerja, 1(2), 101-110. 
Given, Lisa. (2012). PENGARUH KUALITAS PELAYANAN, CITRA MEREK DAN HARGA TIKET TERHADAP KEPUTUSAN PENGGUNAAN JASA PO RAMAYANA MAGELANG (Studi Kasus pada Pengguna Bus Ramyana VIP). The SAGE Encyclopedia of Qualitative Research Methods. https://doi.org/10.4135/9781412963909.n164

Indriastuty, Nina. (2020). Pengaruh bauran promosi terhadap minat pengunjung Wisata budaya pesta adat Erau. Jurnal Manajemen Komunikasi, 4(2), 61. https://doi.org/10.24198/jmk.v4i2.23264

Isnaini, Putri Rizkiah, \& Abdillah, Yusri. (2018). Pengaruh Citra Merek Destinasi Terhadap Keputusan Berkunjung dan Kepuasan Serta Dampaknya Pada Minat Kunjungan ( Survei pada Pengunjung Taman Rekreasi Selecta Kota Batu yang termasuk dalam Kategori Generasi Millennial ). Jurnal Administrasi Bisnis (JAB), 5(2), 122-129.

Mardiyani, Yuyun, \& Murwatiningsih, Murwatiningsih. (2015). Pengaruh Fasilitas Dan Promosi Terhadap Kepuasan Pengunjung Melalui Keputusan Berkunjung Sebagai Variabel Intervening Pada Objek Wisata Kota Semarang. Management Analysis Journal, 4(1), 65-75. https://doi.org/10.15294/maj.v4i1.7220

Meilisa, Veni Fitra, \& Firdaus, Muhammad. (2018). Strategi komunikasi dinas pariwisata, kepemudaan dan olahraga, dan kebudayaan kabupaten indragiri hilir dalam menarik minat pengunjung objek wisata pantai solop. Jom Fisip, 5(1), 1-16.

Negara, A. A. N. D. .., Arifiin, Zainul, \& Nuralam, Inggang P. (2018). Pengaruh Kualitas Produk dan Brand Image terhadap Minat Beli (Survei Pada Pembeli di Gerai Starbucks di Kota Surabaya). Jurnal Administrasi Bisnis (JAB), 61(2), 202-209.

Putra, Gagah Bimo Setyo, Kumadji, Srikandi, \& Hidayat, Kadarisman. (2015). PENGARUH CITRA PERUSAHAAN TERHADAP MINAT BERKUNJUNG DAN KEPUTUSAN BERKUNJUNG (Survei pada Pengunjung Taman Rekreasi PT.Selecta, Kota Batu, Jawa Timur). Jurnal Administrasi Bisnis S1 Universitas Brawijaya, 26(2), 1-8.

Rizky, Muhammad Fakhru, \& Yasin, Hanifa. (2014). Pengaruh Promosi Dan Harga Terhadap Minat Beli Perumahan Obama PT.Nailah Adi Kurnia Sei Mencirim Medan. Jurnal Manajemen Dan Bisnis, 14(02), 135-143.

Rossy, \& Meisyaroh, Siti. (2017). Pengaruh Brand Image Air Asia Terhadap Keputusanpembelian Tiket Maskapai Penerbangan Pada Konsumen Pegangsaan Dua. Manajemen Pemasaran, 24(2), 145153.

Syaifulloh, Muhammad. (2021). Strategi Program Technopreneurship dan Marketing Public Relation terhadap Pengembangan Usaha Mikro, Kecil dan Menengah (UMKM). Jurnal Manajemen Dan Bisnis: Performa, 18(1), 1-13.

UU-10-Tahun 2009. (n.d.). Undang Undang No. 10 Tahun 2009 Tentang Kepariwisataan. 